\title{
Interaction between retanning agents and wet white tanned by a novel bimetal complex tanning agent
}

\author{
Wanli Huang ${ }^{1}$, Ying Song ${ }^{1}$, Yue Yu ${ }^{1}$, Ya-nan Wang ${ }^{1,2^{*}}$ and Bi Shi ${ }^{1,2}$
}

\begin{abstract}
A promising and practical chrome-free tanning system has been developed based on a novel Al-Zr bimetal complex tanning agent. However, to achieve satisfactory resultant leather, the retanning process that is compatible with this emerging tannage needs to be investigated systematically. This paper aims to explore the interaction between the bimetal complex tanned wet white and retanning agents. The isoelectric point (pl) of wet white was 7.2, which was nearly the same as wet blue. The electropositivity of wet white was even higher than that of wet blue during post-tanning processes, resulting in higher uptake rate of retanning agents. The distribution of various retanning agents in wet white was analyzed by pl measurement of layered leather and fluorescent tracing technique. The retanning agents were unevenly distributed throughout the cross-section, which might be an important restriction factor in obtaining satisfactory organoleptic properties of the crust leather. This fact is mainly due to the strong electrostatic interaction between anionic retanning agents and wet white. Applying a high dosage of multiple retanning agents in a proper sequence of addition benefited the full penetration of retanning agents in leather matrix and thus improved the organoleptic properties of crust leather. This work provides guidance for optimizing retanning process of the wet white leather.
\end{abstract}

Keywords: Wet white, Retanning, Chrome-free tanning, Isoelectric point, Fluorescent tracing technique

\section{Introduction}

Nowadays, the demand for chrome-free tanning technology has increased significantly in China [1-4] since conventional chrome tannage is subjected to great restriction due to the discharges of $\mathrm{Cr}$-containing wastewater and solid wastes [5, 6]. However, few of the existing chromefree tanning technologies have been widely used as alternatives of chrome tannage on an industrial scale. One reason is that most of the wet white leathers (semi-finished products tanned with chrome-free tanning agents) exhibit insufficient extent of collagen fiber separation [7, 8], poor storage stability and low shrinkage temperature [9]. Another reason is the fact that chrome-free resultant

\footnotetext{
* Correspondence: wangyanan@scu.edu.cn

'Key Laboratory of Leather Chemistry and Engineering (Sichuan University), Ministry of Education, Chengdu 610065, China

${ }^{2}$ National Engineering Laboratory for Clean Technology of Leather Manufacture, Sichuan University, Chengdu 610065, China
}

leathers commonly present inferior organoleptic properties compared with chrome leather [10].

Retanning is regarded as a crucial process in improving physical and organoleptic properties of leather [11]. The binding of retanning agents (mostly anionic chemicals) on the tanned leather mainly depends on the electrostatic force between them $[12,13]$. Chrome tanned semi-finished leather (wet blue) possesses high isoelectric point (pI, commonly over 7.0) and can firmly fix the anionic retanning agents through ionic bond [14]. Moreover, the uniform penetration and distribution of retanning agents in chrome tanned leather were observed by using fluorescent tracing technique, which led to satisfactory organoleptic properties of crust leather [12, 15]. In fact, the current retanning agents and retanning technologies are designed to match up with chrome tanning system and may be not suitable for chrome-free tannage in consideration of the changed $\mathrm{pI}$

\section{Springer Open}

(0) The Author(s). 2020 Open Access This article is licensed under a Creative Commons Attribution 4.0 International License, which permits use, sharing, adaptation, distribution and reproduction in any medium or format, as long as you give appropriate credit to the original author(s) and the source, provide a link to the Creative Commons licence, and indicate if changes were made. The images or other third party material in this article are included in the article's Creative Commons licence, unless indicated otherwise in a credit line to the material. If material is not included in the article's Creative Commons licence and your intended use is not permitted by statutory regulation or exceeds the permitted use, you will need to obtain permission directly from the copyright holder. To view a copy of this licence, visit http://creativecommons.org/licenses/by/4.0/. 
of wet white (mostly less than 5.0) $[14,16]$. Therefore, the retanning process for chrome-free tanning system should be systematically investigated and redesigned to upgrade the quality of chrome-free leather.

We recently developed a promising and practical chromefree tanning system based on a novel $\mathrm{Al}-\mathrm{Zr}$ bimetal complex tanning agent [17]. A well-prepared oxidized starch ligand was introduced into the complex tanning agent, which resulted in excellent tanning performance $[18,19]$. The wet white tanned by this chrome-free tanning agent showed similar extent of collagen fiber separation, storage stability and charge characteristic compared with wet blue $[17,20]$. In this study, to make satisfactory resultant leather, the retanning of the wet white was explored. The penetration and distribution of retanning agents in wet white were analyzed by $\mathrm{pI}$ measurement of leather and fluorescent tracing of retanning agent. The uptake of retanning agents by wet white and the organoleptic properties of leather were also evaluated. The investigation on the interaction between the wet white and typical retanning agents is expected to guide the development and practical application of the chromefree tanning system.

\section{Experimental}

\subsection{Materials}

The bimetal complex tanning agent was prepared by blending a highly oxidized starch ligand (15 wt\%, the preparation method was reported in our previous work [17]), $\mathrm{Al}_{2}\left(\mathrm{SO}_{4}\right)_{3} \cdot 18 \mathrm{H}_{2} \mathrm{O}$ (60 wt\%), and $\mathrm{Zr}\left(\mathrm{SO}_{4}\right)_{2} \cdot 4 \mathrm{H}_{2} \mathrm{O}$ (25 wt\%). Pickled cattle hide was tanned by $10 \%$ bimetal complex tanning agent (based on limed weight, the same below) at $25^{\circ} \mathrm{C}$ for $3 \mathrm{~h}$ and basified with $1.1 \%$ magnesium oxide to $\mathrm{pH} 4.0$. Then $200 \%$ water was added to run at $40{ }^{\circ} \mathrm{C}$ for another $2 \mathrm{~h}$ to obtain wet white [18]. Wet blue leather (tanned by a conventional process with $7 \%$ chrome tanning agent, and basified to $\mathrm{pH} 4.0$ in the end) was supplied by a local tannery. Mimosa extract (ME, tannin content 72\%), melamine-formaldehyde resin (MR, solid content 94\%), acrylic resin (AR, copolymerized by acrylic acid and methacrylic acid, $31 \mathrm{wt} \%$ ) and amphoteric acrylic resin (AAR, copolymerized by dimethyl diallyl ammonium chloride and acrylic acid, $30 \mathrm{wt} \%)$ were provided by a leather chemical company. Rhodamine B isothiocyanate (RBITC) and Sephadex G-50 were purchased from Sigma-Aldrich Co. LLC. (Saint Louis, USA). 5-aminofluorescein (AF) was purchased from Aladdin Biochemical Technology Co., Ltd. (Shanghai, China).

RBITC-labeled MR (RBITC-MR), AF-labeled AR (AFAR) and AF-labeled AAR (AF-AAR) were synthesized according to our previous work [15, 21]. In brief, $25 \mathrm{~mL}$ of MR solution $(5 \mathrm{mg} / \mathrm{mL})$ was reacted with $5 \mathrm{~mL}$ of RBITC aqueous solution $(5 \mathrm{mg} / \mathrm{mL})$ in the dark at $\mathrm{pH}$ 9.16 and $4{ }^{\circ} \mathrm{C}$ for $10 \mathrm{~h}$. The blend was purified using a Sephadex G-50 gel-filtration column with ultrapure water at a flow rate of $1.0 \mathrm{~mL} / \mathrm{min}$. The eluate with RBITC-MR was collected and freeze-dried.

Sixty $\mathrm{mL}$ of AR/AAR was activated by $15 \mathrm{~mL}$ of dicyclohexylcarbodiimide $(0.5 \mathrm{~mol} / \mathrm{L}$ in diethyl ether $)$ at $25^{\circ} \mathrm{C}$ for $5 \mathrm{~min}$, and then the organic phase was collected. The remaining aqueous phase was activated once more as described above. The two-time organic phase was combined and reacted with $0.4 \mathrm{~mL}$ of $\mathrm{AF}(100 \mathrm{mmol} / \mathrm{L}$ in dimethylformamide) under stirring in the dark at $25^{\circ} \mathrm{C}$ for $10 \mathrm{~min}$. Then $6 \mathrm{~mL}$ of $1 \mathrm{mmol} / \mathrm{L}$ sodium hydroxide solution was added to extract AF-labeled product into the aqueous phase. Purification and freeze-drying were conducted as described above to obtain AF-AR/AF-AAR.

\subsection{Post-tanning processes of wet white and wet blue}

A piece of wet white leather $(80 \mathrm{~cm} \times 60 \mathrm{~cm}$, shaved to thickness $1.0 \mathrm{~mm}$ ) was processed using a conventional post-tanning recipe described as below. It was weighed, rewetted with $0.5 \%$ non-ionic degreasing agent (based on shaved weight, the same below) and $400 \%$ water at $\mathrm{pH} 3.8$ and $35^{\circ} \mathrm{C}$ for $40 \mathrm{~min}$, and then neutralized to $\mathrm{pH} 6.0$ with $1.2 \%$ sodium bicarbonate and $200 \%$ water at $35^{\circ} \mathrm{C}$ for 120 min. After washing, it was retanned with $11 \%$ retanning agents (3\% AR, 3\% MR, and 5\% ME) and 100\% water at $35^{\circ} \mathrm{C}$ for $120 \mathrm{~min}$, and then fixed by formic acid to $\mathrm{pH} 4.0$. Subsequently, it was fatliquored with $14 \%$ synthetic fatliquoring agents at $50^{\circ} \mathrm{C}$ for $60 \mathrm{~min}$ and fixed by formic acid to $\mathrm{pH}$ 3.8. Dry finishing was performed to obtain crust leather. Leather samples were collected after neutralizing, retanning and fatliquoring processes to measure their pIs. Water samples at the beginning and the end of retanning and fatliquoring processes were also collected to determine the uptake rates of retanning agents and fatliquoring agents. Softness and fullness of crust leather were measured. Wet blue was processed in the same way as described above for comparison.

\subsection{Retanning trials of wet white}

Eight pieces of wet white $(20 \mathrm{~cm} \times 20 \mathrm{~cm})$ were rewetted and neutralized as described in 2.2. The neutralized leathers were divided into 8 groups and retanned according to the procedures detailed in Table 1 . Then they were sampled and evenly split into three layers. The pIs of each layer and the entire leather were measured. As for group S1-S4, water samples at the beginning and the end of retanning were collected to determine the uptake rates of retanning agents. Fatliquoring and dry finishing were proceeded to obtain crust leathers. The fullness of the crust leathers was evaluated afterwards.

\subsection{Observation of retanning agents distribution in leather}

A piece of wet white $(20 \mathrm{~cm} \times 20 \mathrm{~cm})$ was rewetted and neutralized as described in 2.2. Eight samples $(5 \mathrm{~cm} \times 5$ 
Table 1 Retanning trials

\begin{tabular}{|c|c|c|}
\hline & Group & Retanning procedure \\
\hline \multirow[t]{4}{*}{ Single retanning agent } & a & $35^{\circ} \mathrm{C}, 100 \%$ water, $3 \% \mathrm{ME}$, running for $90 \mathrm{~min}$. \\
\hline & $b$ & $35^{\circ} \mathrm{C}, 100 \%$ water, $3 \% \mathrm{MR}$, running for $90 \mathrm{~min}$. \\
\hline & c & $35^{\circ} \mathrm{C}, 100 \%$ water, $3 \%$ AR, running for $90 \mathrm{~min}$. \\
\hline & $d$ & $35^{\circ} \mathrm{C}, 100 \%$ water, $3 \%$ AAR, running for $90 \mathrm{~min}$. \\
\hline \multirow[t]{4}{*}{ Multiple retanning agents } & S1 & $\begin{array}{l}35^{\circ} \mathrm{C}, 100 \% \text { water, } 3 \% \mathrm{AR} \text {, running for } 30 \mathrm{~min} \text {. } \\
\text { Adding } 3 \% \mathrm{ME} \text { and } 3 \% \mathrm{MR} \text {, and running for another } 60 \mathrm{~min} \text {. }\end{array}$ \\
\hline & $\mathrm{S} 2$ & $\begin{array}{l}35^{\circ} \mathrm{C}, 100 \% \text { water, } 3 \% \mathrm{ME} \text { and } 3 \% \mathrm{MR} \text {, running for } 30 \mathrm{~min} \text {. } \\
\text { Adding } 3 \% \mathrm{AR} \text {, and running for another } 60 \mathrm{~min} \text {. }\end{array}$ \\
\hline & S3 & $\begin{array}{l}35^{\circ} \mathrm{C}, 100 \% \text { water, } 3 \% \mathrm{AAR} \text {, running for } 30 \mathrm{~min} \text {. } \\
\text { Adding } 3 \% \mathrm{ME} \text { and } 3 \% \mathrm{MR} \text {, and running for another } 60 \mathrm{~min} \text {. }\end{array}$ \\
\hline & S4 & $\begin{array}{l}35^{\circ} \mathrm{C}, 100 \% \text { water, } 3 \% \mathrm{ME} \text { and } 3 \% \mathrm{MR} \text {, running for } 30 \mathrm{~min} \text {. } \\
\text { Adding 3\% AAR, and running for another } 60 \mathrm{~min} \text {. }\end{array}$ \\
\hline
\end{tabular}

$\mathrm{cm}$ ) were collected from the neutralized leather, and then retanned according to the procedures shown in Table 1. It should be noted that the retanning agents were replaced with fluorescent ones, viz. RBITC-MR, AF-AR and AF-AAR in this trial. After retanning, the samples were cut into vertical sections with a thickness of $20 \mu \mathrm{m}$ using a freezing microtome (CM1950, Leica, Germany). RBITC-MR, AF-AR and AF-ARR in the sections were observed and located using a fluorescence microscope (Ti-U, Nikon, Japan). In addition, the samples retanned with ME were cut along the vertical direction, and the vertical sections were directly observed by a stereo microscope (SZX12, Olympus, Japan) to locate $M E$ in leather. The fluorescence and stereo micrographs were processed by Image J software to calculate the relative content and the penetration rate of fluorescent retanning agent in leather [22].

\subsection{Analytical methods}

\subsubsection{Zeta potential and particle size of retanning agent}

The zeta potentials of ME, MR, AR and AAR aqueous solutions $(1 \mathrm{mg} / \mathrm{mL}$ for each) were determined in the post-tanning $\mathrm{pH}$ range $(\mathrm{pH} 3-7)$ at $25^{\circ} \mathrm{C}$ using a particle size \& zeta potential analyzer (NanoBrook Omni, Brookhaven, USA). The particle size distributions of the retanning agent solutions at $\mathrm{pH} 6.0$ and 4.0 were also determined by this instrument.

\subsection{2 pl of leather}

The $\mathrm{pI}$ of leather was determined according to our previous work [14]. In brief, leather samples were dried at $45^{\circ} \mathrm{C}$ for $24 \mathrm{~h}$ and then ground into fibers using a cutting mill (SM 100, Retsch, Germany). Then $10 \mathrm{~g}$ leather sample was dispersed in $400 \mathrm{~mL}$ water. $\mathrm{HCl}$ solution or $\mathrm{NaOH}$ solution $(0.1 \mathrm{~mol} / \mathrm{L})$ was added to adjust the $\mathrm{pH}$ of the suspension. The suspension was vibrated at $150 \mathrm{r} /$ min in $30^{\circ} \mathrm{C}$ water bath for $30 \mathrm{~min}$. The zeta potentials of leather sample at different $\mathrm{pH}$ values were determined using a zeta potential analyzer (Mütek SZP-10, BTG, Germany). The $\mathrm{pH}$ value at zero point of zeta potential was identified as the pI of leather.

\subsubsection{Uptake rate of post-tanning chemicals}

The total organic carbon concentrations of the water samples were determined using a TOC analyzer (Vario TOC, Elementar, Germany). The uptake rate of a retanning/fatliquoring agent was calculated by the total organic carbon concentrations of the water samples at the beginning and the end of the process.

\subsubsection{Softness and fullness of crust leather}

The softness of crust leather was measured according to a standard method [23]. The fullness of crust leather was evaluated through measuring the compressed and resilient thicknesses of the crust leathers using the method described in literature [24, 25]. Higher compressed and resilient thicknesses indicate better fullness of the crust leather.

\section{Results and discussion}

\subsection{Charge properties of leather during post-tanning}

Variation in the charge properties of wet white during post-tanning processes was investigated, and wet blue was used for comparison. As shown in Fig. 1a and b, the pI of wet white was equal to that of wet blue, indicating similar charge properties of the two tanned leathers. The pIs of neutralized wet white and wet blue leathers remained unchanged. The electropositivity of leather surface decreased sharply in neutralizing process (see the change in zeta potential in Fig. 1a and b) as the $\mathrm{pH}$ of float rose from 3.8 to 6.0. In tanning theories, this phenomenon suggests that retanning agents (mostly anionic chemicals) tend to penetrate into neutralized leather matrix rather than binding on the leather surface at the beginning of retanning [26]. When $\mathrm{pH}$ was adjusted to 4.0 at the end of retanning, the anionic retanning 

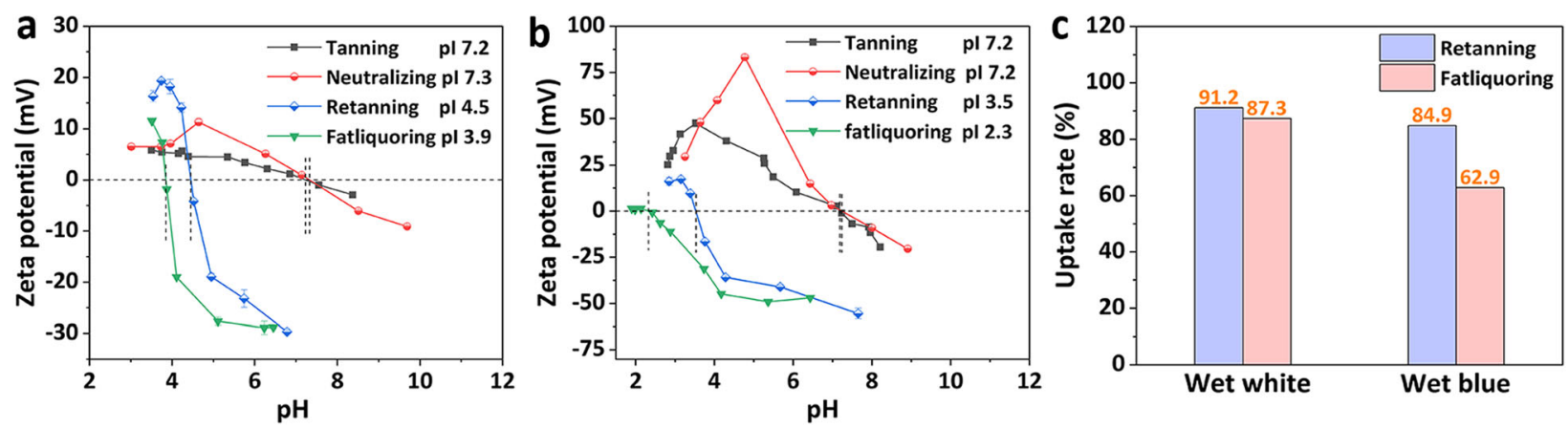

Fig. 1 pls of wet white (a) and wet blue (b) in post-tanning processes; (c) uptake rates of retanning agents and fatliquoring agents in wet white and wet blue

agents were finally fixed in leather through electrostatic interaction, thereby resulting in the reduction in $\mathrm{pI}$ of leather. The $\mathrm{pI}$ of retanned wet white was higher than that of wet blue, suggesting that the electropositivity of wet white was higher and more stable than that of wet blue after retanning. The retanned wet white was still electropositive at $\mathrm{pH} 4.0$, showing greater potential for binding with the following fatliquoring agents. This hypothesis was proven by Fig. 1c where the uptake rates of retanning agents and fatliquoring agents in wet white were higher than those in wet blue. However, wet-whitebased crust leather showed worse organoleptic properties (softness and fullness) than those of wet blue based crust leather (Additional files 1 Fig. S1). This result may be attributed to the uneven distribution of retanning agents in wet white, in consideration of the high electropositivity of wet white. Therefore, the interactions between the wet white and retanning agents were further investigated in the following sections.

\subsection{Interaction between wet white and single retanning agent}

Electrostatic interaction is considered as one of the main reaction types between leather and retanning agents [12, 13]. Hence, the charge properties of both retanning agents and retanned wet white were analyzed firstly to investigate the interaction. Three typical anionic retanning agents, viz. ME with phenolic hydroxyl and sulfonic groups, MR with hydroxymethyl and sulfonic groups and AR with carboxyl groups, were chosen in this study. Zeta potential analysis (Fig. 2) shows that they were negatively charged in the $\mathrm{pH}$ range from 7 to 3 , which means that they maintained in electronegative state during retanning process ( $\mathrm{pH}$ changed from 6 to 4). Retanning with the three chemicals separately led to a decrease in the pI of wet white from 7.2 (Fig. 1a) to 5.96.5 (Fig. 3a). This fact was mainly ascribed to the electrostatic bonding between the anionic groups of the retanning agents and the amino groups of leather collagen fibers. Moreover, coordination reaction also occurred between the anionic groups of retanning agents and $\mathrm{Al}-\mathrm{Zr}$ bimetal complex tanning agent fixed in leather $[27,28]$. AAR, an amphoteric retanning agent containing carboxyl and quaternary ammonium groups, possessed a pI of 3.83 (Fig. 2). The introduction of AAR resulted in a reduction in the $\mathrm{pI}$ of wet white as well. However, the pI of AAR retanned wet white (pI 6.6, as shown in Fig. 3a) was higher than those retanned by the other three anionic chemicals because the zwitterionic property of AAR can give the retanned leather a certain number of positive groups.

Then the $\mathrm{pI}$ of each layer of the retanned wet white was measured to evaluate the distribution uniformity of retanning agents in leather. The $\mathrm{pI}$ of the middle layer was higher than those of grain and flesh layers for all the four groups (Fig. 3b), indicating that more retanning agents were fixed in the grain and flesh layers than in the middle layer. These results indicated that 3\% single retanning agent cannot penetrate and uniformly distribute in wet white. Stereo microscopy and fluorescence microscopy on the cross-sections of the retanned wet white further demonstrated this finding. As shown in Fig. 4a, the visual distributions of ME (in brown), RBITC-MR (in red), AF-AR (in green) and AF-AAR (in green) were uneven on the entire cross-section of wet white. The relative contents and penetration rates of the retanning agents calculated from the micrographs (Fig. $4 \mathrm{~b})$ also show that the retanning agents were mainly located in the grain and flesh layers and did not penetrate into the middle layer of wet white. This phenomenon could be ascribed to three reasons. Firstly, the electropositivity of the neutralized wet white was still too high to retard the electrostatic bonding of anionic chemicals at the beginning of retanning ( $\mathrm{pH}$ 6.0), although neutralizing had masked a part of positive charges of wet white (see the decrease in zeta potential of wet white with the increase in $\mathrm{pH}$ from 4.0 to 6.0 during neutralizing, Fig 1a). The evidence was that AAR showed higher penetration 


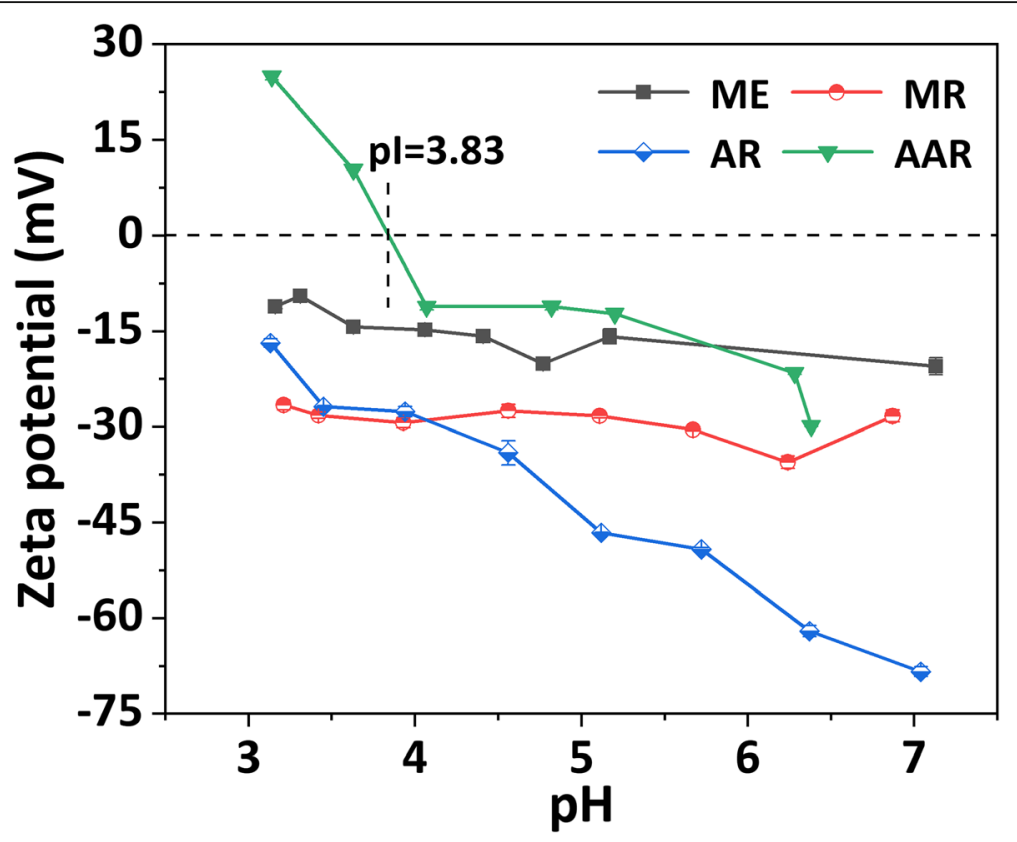

Fig. 2 Effect of pH on zeta potential of retanning agent

rate than the other three anionic chemicals due to its zwitterionic property. Secondly, the dosage of the retanning agent (3\%) was not enough to maintain the osmotic pressure that ensured the complete penetration of retanning agent. At last, the penetration of a retanning agent may be influenced by its particle size in consideration of the porous structure of leather matrix. AR with large particle size (diameter $696.46 \mathrm{~nm}$ at $\mathrm{pH}$ 6.0, Fig. S2) resulted in low penetration rate $(29.7 \%$, Fig $4 \mathrm{~b})$. MR (diameter $6.75 \mathrm{~nm}$ at pH 6.0, Fig. S2) had similar particle size to AAR (diameter $2.62 \mathrm{~nm}$ at $\mathrm{pH}$ 6.0, Fig. S2). However, the penetration rate of MR (52.8\%) was much lower than that of AAR (90.0\%). This fact suggested that the electrostatic interaction between wet white and retanning agents plays a more essential role in the retanning agents distribution compared with the particle size of retanning agents.

\subsection{Interaction between wet white and multiple retanning agents}

In practice, various types of retanning agents are used together in retanning to improve the properties of leather. Hence, the interaction between wet white and
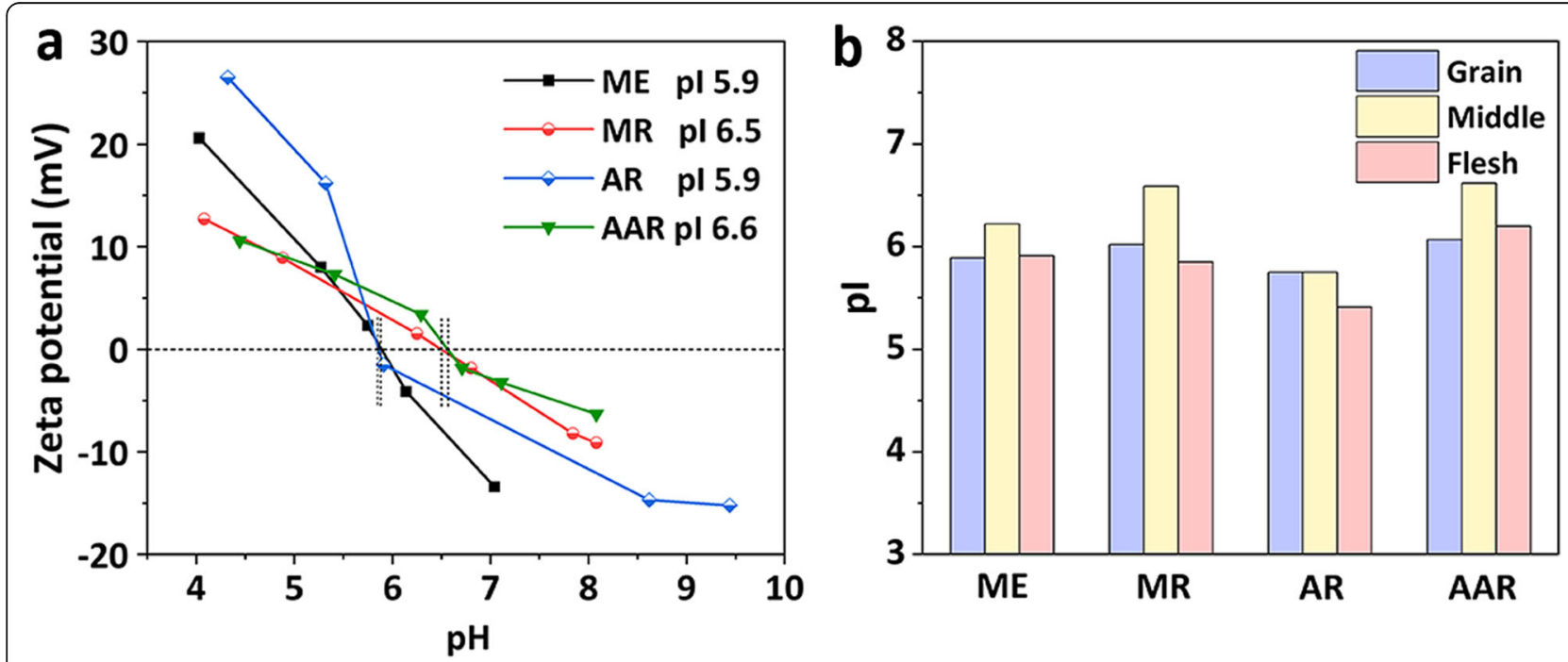

Fig. 3 pls of the entire wet white (a) and each layer of wet white (b) retanned with single retanning agent 

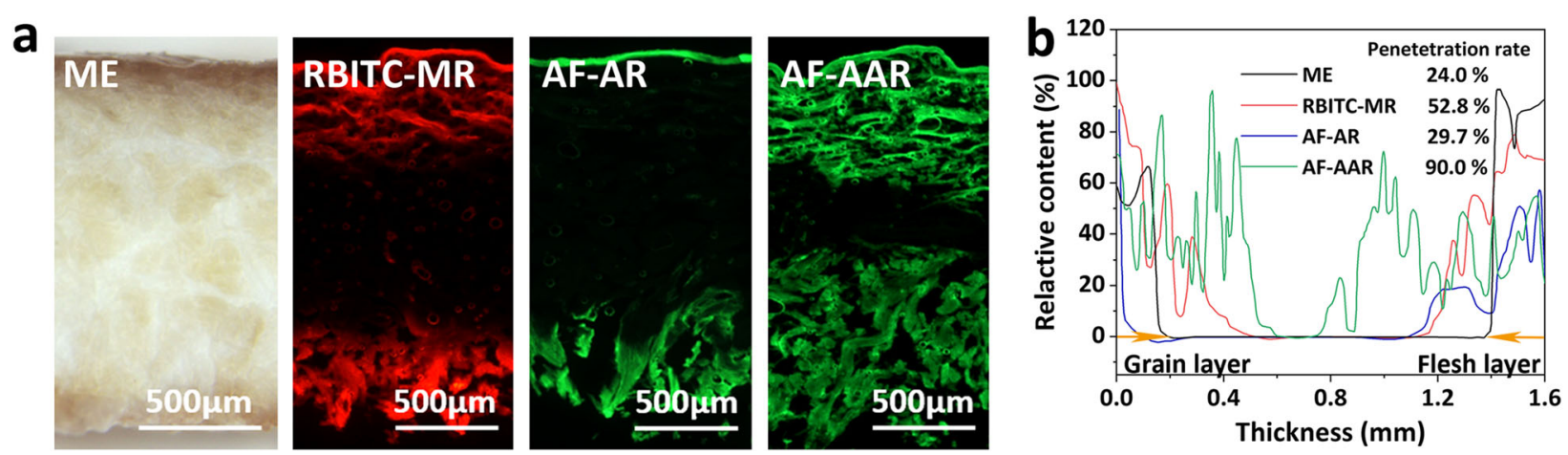

Fig. 4 a Stereo micrograph and fluorescence micrographs of cross-sections of wet white retanned with single retanning agent; (b) relative contents and penetration rates of the retanning agents obtained by analysis of (a) using Image J software

multiple retanning agents was investigated. As shown in Fig. 5, the pIs of the three layers of retanned wet white differ greatly for all the four groups $(\mathrm{S} 1-\mathrm{S} 4$, detailed in Table 1), implying that the distribution of retanning agents in wet white was still uneven when $9 \%$ multiple retanning agents were used. This result was further confirmed by stereo microscopy and fluorescence microscopy on the cross-sections of the retanned wet white. Figure 6 show that retanning agents (ME in dark grey, $M R$ in red, AR and AAR in green) were mainly distributed in grain and flesh layers. Retanning groups S1 and S4 led to higher penetration rate of retanning agents compared with groups S2 and S3, suggesting that the adding sequence is crucial for the penetration of retanning agents. S1 and S2 employed the same types and amount of retanning agents, but adopted different adding sequences. In S1, AR was firstly added, followed by $\mathrm{ME}$ and MR after $30 \mathrm{~min}$. AR has the highest electronegativity among the retanning agents (see Fig. 2) and can most effectively reduce the surface electropositivity of wet white in the initial stage of retanning, which favors penetration of all the retanning agents. This should be the reason that $\mathrm{S} 1$ led to higher penetration rate of retanning agents compared with S2. S3 and S4 also used the same retanning agents with different sequences of addition. In S3, zwitterionic AAR that has the highest electropositivity among the retanning agents (see Fig. 2) was firstly added, followed by ME and MR after $30 \mathrm{~min}$. This approach hindered the reduction of surface electropositivity of wet white, and thus led to lower penetration rate of ME and MR compared with S4 where AAR was finally added.

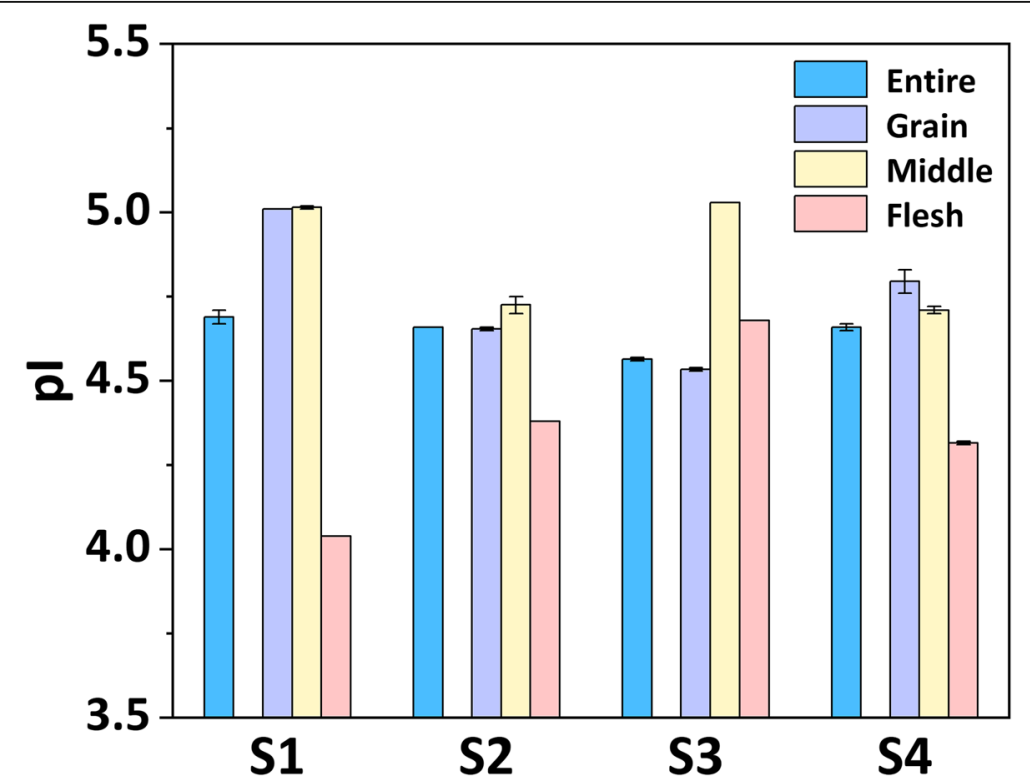

Fig. 5 pls of the entire wet white and each layer of wet white retanned with multiple retanning agents (S1: $3 \%$ AR for 30 min, then adding $3 \%$ ME and 3\% MR for 60 min; S2: 3\% ME and 3\% MR for 30 min, then adding 3\% AR for 60 min; S3: $3 \%$ AAR for 30 min, then adding 3\% ME and 3\% MR for $60 \mathrm{~min}$; S4: 3\% ME and 3\% MR for $30 \mathrm{~min}$, then adding 3\% AAR for $60 \mathrm{~min}$ ) 
a $\mathrm{S1}: 3 \%$ AR for $30 \mathrm{~min}$, then adding $3 \% \mathrm{ME}$ and $3 \% \mathrm{MR}$ for $60 \mathrm{~min}$
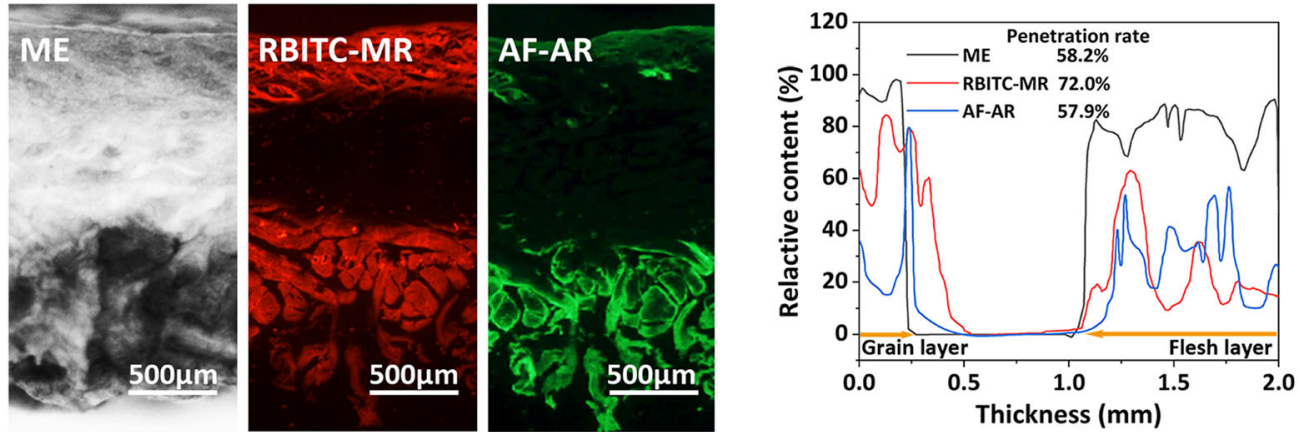

S2: 3\% ME and 3\% MR for 30min, then adding 3\% AR for $60 \mathrm{~min}$
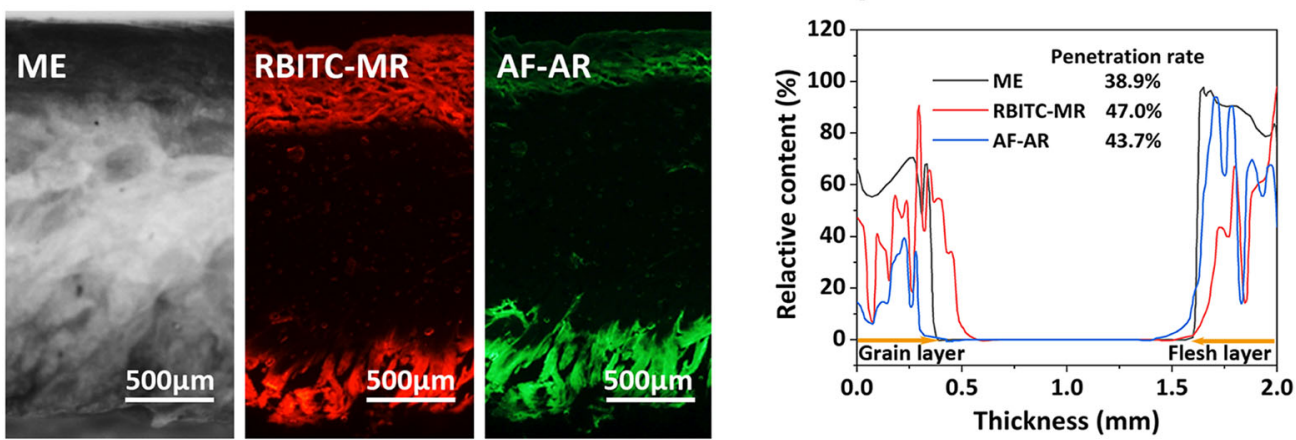

C S3: $3 \%$ AAR for $30 \mathrm{~min}$, then adding $3 \% \mathrm{ME}$ and $3 \% \mathrm{MR}$ for $60 \mathrm{~min}$
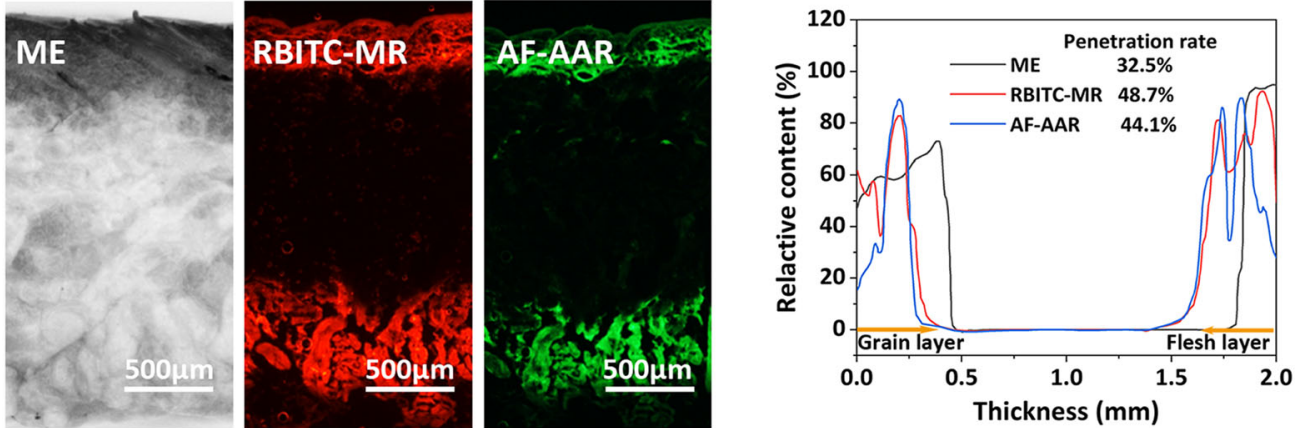

S4: 3\% ME and 3\% MR for 30min, then adding 3\% AAR for $60 \mathrm{~min}$
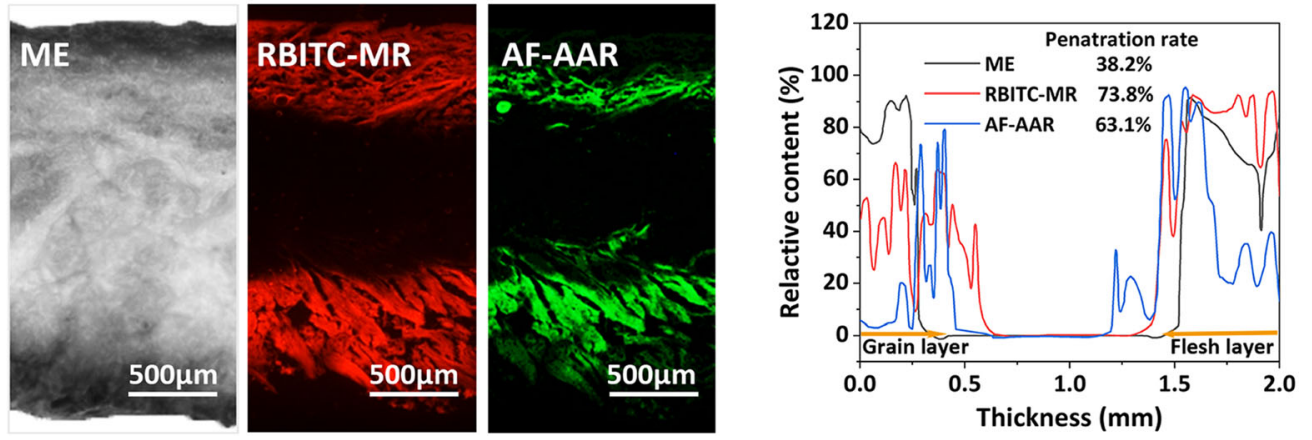

Fig. 6 Stereo micrograph and fluorescence micrographs of cross-sections of wet white retanned with multiple retanning agents, and relative contents and penetration rates of the retanning agents (a: group S1; b: group S2; c: group S3; d: group S4) 

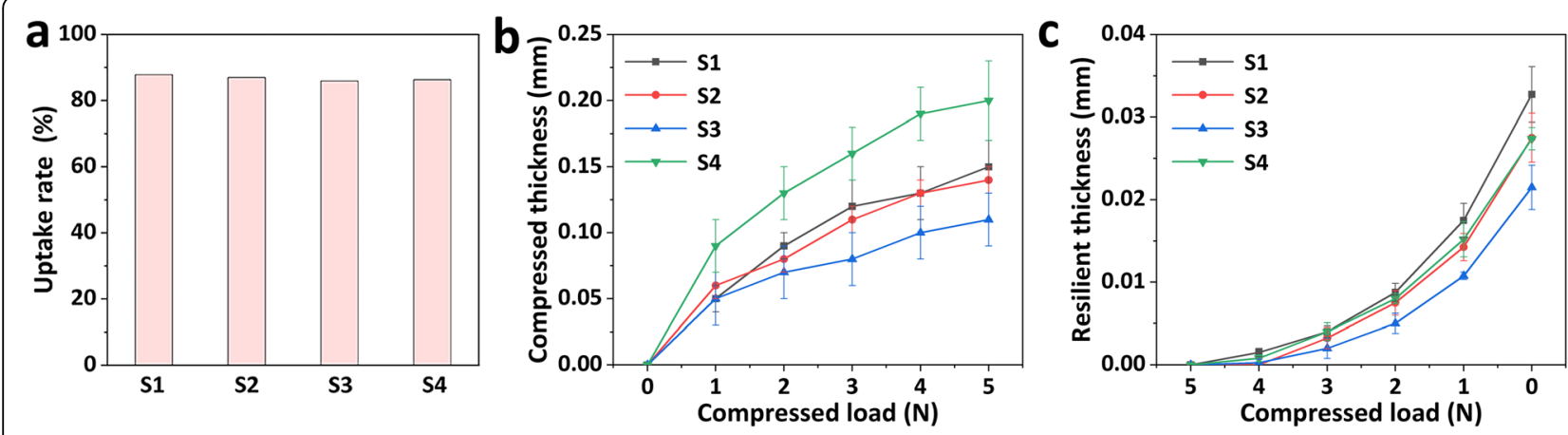

Fig. 7 Uptake rates of retanning agents in wet white (a); compression (b) and resilience (c) performance of crust leathers

The fullness of the crust leathers retanned by procedures S1 and S4 was higher than those retanned by procedures S2 and S3 (see higher compressed and resilient thicknesses shown in Fig. 7). Considering that the uptake rates of retanning agents were nearly the same for the four groups (Fig. 7a), the fullness of the crust leathers is mainly determined by the penetration performance of the retanning agents. Higher penetration rate and uniform distribution of retanning agents result in more satisfactory organoleptic properties of crust leather.

The penetration rates of the anionic retanning agents (ME, MR, AR) in groups S1 were higher than those using single retanning agent (Fig. 4b). Although the penetration rate of zwitterionic AAR in group S4 was lower than that using single AAR (probably due to the binding interaction between AAR and the anionic agents), the penetration of the anionic agents (ME and MR) in groups S4 was enhanced. These results indicate that the use of a large amount of multiple retanning agents can increase the osmotic pressure and thus promote the penetration of anionic retanning agents in wet white [15].

It should be noted that the flesh layer of groups S1 and S4 still fixed higher content of retanning agents compared with grain and middle layers, which was in accordance with the data in Fig. 5, where the flesh layer of groups S1 and S4 showed lower pI than those of grain and middle layers. The reason for the uneven distribution of retanning agents can be explained by the strong binding interaction between the high electropositive wet white and the electronegative retanning agents.

Based on the results above, some strategies to enhance the penetration of retanning agents and improve the organoleptic properties of wet white based leather are proposed as below. 1) AR with strong electronegativity and binding capacity can be used in the initial stage of retanning to seal a majority of positive-charged groups in wet white and improve the penetration of other retanning agents. 2) Zwitterionic AAR can be used in the later stage of retanning to further promote the penetration of other retanning agents.

\section{Conclusions}

Wet white leather tanned by a novel bimetal complex tanning agent showed higher electropositivity than wet blue during post-tanning processes, leading to a higher uptake rate of retanning agents. However, the penetration and distribution of retanning agents were uneven throughout the cross-section of retanned leather, thereby resulting in unsatisfactory organoleptic properties of crust leather. Using a high amount of multiple retanning agents in proper sequence is recommended to facilitate the penetration of retanning agents. Further research should focus on developing novel zwitterionic retanning agents with appropriate pI that fit with the charge property of wet white, and optimizing a balanced solution for uniform distribution and fixation of retanning agents in leather.

\section{Supplementary information}

Supplementary information accompanies this paper at https://doi.org/10. 1186/s42825-020-00023-2.

Additional file 1. Figure S1.Softness (a), compression performance (b), and resilience performance (c) of crust leathers based on wet white and wet blue Figure S2. Particle size distribution of retanning agent at $\mathrm{pH} 6$ and $\mathrm{pH}$ 4: (a, b) ME, (c, d) MR, (e, f) AR, $(g, h)$ AAR

\section{Abbreviations}

AAR: amphoteric acrylic resin; AF: 5-aminofluorescein; AR: acrylic resin; ME: Mimosa extract; MR: melamine-formaldehyde resin; pl: isoelectric point; RBITC: Rhodamine B isothiocyanate

\section{Acknowledgements}

Not applicable.

\section{Authors' contributions}

WH was a major contributor in designing and performing the experiments, and drafting the manuscript. YS interpreted the penetration of retanning agents in leather by using fluorescent tracing technique. YY performed the tanning process of wet white. YW was a major contributor in the conception of the study, the discussion of the results and the revision of the manuscript. 
BS analyzed the results and revised the manuscript. All authors read and approved the final manuscript.

\section{Funding}

This work was financially supported by the National Natural Science Foundation of China (21506129)

\section{Availability of data and materials}

All data from this study are presented in the paper and the additional file.

\section{Competing interests}

The authors declare that they have no competing interests.

Received: 3 March 2020 Accepted: 30 March 2020

Published online: 15 April 2020

\section{References}

1. Xiao YH, Wang $\mathrm{CH}$, Sang J, Lin W. A novel non-pickling combination tanning for chrome-free leather based on reactive benzenesulphonate and tannic acid. J Am Leather Chem As. 2020;115(1):16-22.

2. Zhou YX, Ma JZ, Gao DG, Li WB, Shi JB, Ren HJ. A novel chrome-free tanning approach based on sulfonatedtetraphenyl calix[4]resorcinarene: preparation and application. J Clean Prod. 2018;201:668-77.

3. Ding W, Wang YN, Zhou JF, Shi B. Effect of structure features of polysaccharides on properties of dialdehyde polysaccharide tanning agent. Carbohyd Polym. 2018;201:549-56.

4. Qiang TT, Gao X, Ren J, Chen XK, Wang XC. A chrome-free and chrome-less tanning system based on the hyperbranched polymer. ACS Sustain Chem Eng. 2015;4(3):701-7.

5. Zhou WJ, Long WJ, Xu T, Peng LQ, Zhang WH. Organic ligands unexpectedly increase the toxicity of chromium(III) for luminescent bacteria. Environ Chem Lett. 2019;17(4):1849-55.

6. Wang YN, Shi B. Progress of inverse chrome tanning technology. Chem Ind Eng Prog. 2019;38(1):639-48.

7. He X, Wang YN, Zhou JF, Wang HB, Ding W, Shi B. Suitability of pore measurement methods for characterizing the hierarchical pore structure of leather. J Am Leather Chem As. 2019;114(2):41-7.

8. Li XX, Wang YN, Li J, Shi B. Effect of sodium chloride on structure of collagen fiber network in pickling and tanning. J Am Leather Chem As. 2016;111(6):230-7.

9. Wang YN, Shi B. Progress of key clean technologies in leather industry. Chem Ind Eng Prog. 2016;35(6):1865-74

10. Taylor MM, Lee J, Bumanlag LP, Balada EH, Brown EM. Treatments to enhance properties of chrome-free (wet white) leather. J Am Leather Chem As. 2011;106(2):35-43.

11. Covington AD. Tanning chemistry: the science of leather. Cambridge: Royal Society of Chemistry; 2011.

12. Song $Y$, Zeng $Y H$, Xiao KL, Wu HP, Shi B. Effect of molecular weight of acrylic resin retanning agent on properties of leather. J Am Leather Chem As. 2017;112(4):128-34

13. Cantera C, Martegani J, Esterelles G, Vergara J. Collagen hydrolysate: 'soluble skin' applied in post-tanning processes. Part 2: interaction with acrylic retanning agents. J Soc Leath Tech Ch. 2002;86(5):195-202.

14. Wang YN, Huang WL, Zhang HS, Tian L, Zhou JF, Shi B. Surface charge and isoelectric point of leather: a novel determination method and its application in leather making. J Am Leather Chem As. 2017;112(7):224-31.

15. Song Y, Wang YN, Zeng YH, Wu HP, Shi B. Quantitative determinations of isoelectric point of retanned leather and distribution of retanning agent. J Am Leather Chem As. 2018:113(7):232-8.

16. Shi JB, Wang CH, Ngai T, Lin W. Diffusion and binding of laponite clay nanoparticles into collagen fibers for the formation of leather matrix. Langmuir. 2018;34(25):7379-85.

17. Yu Y, Wang YN, Ding W, Zhou JF, Shi B. Preparation of highly-oxidized starch using hydrogen peroxide and its application as a novel ligand for zirconium tanning of leather. Carbohyd Polym. 2017;174:823-9.

18. Yu Y, Zeng YH, Wang YN, Liang T, Zhou JF, Shi B. Inverse chrome tanning technology: A practical approach to minimizing $\mathrm{Cr}(\mathrm{III})$ discharge. J Am Leather Chem As. 2020;115(5).

19. Yu Y, Wang YN, Ding W, Zhou JF, Shi B. Effect of catalyst on structure of hydrogen peroxide oxidized starch and its performance as a ligand in zirconium tanning of leather. Fine Chem. 2018;35(11):1928-34.
20. Zhu M, Yu Y, He X, Wang YN, Shi B. Effect of different tannages on microstructure of leather. China Leather. 2019:48(10):1-7.

21. Zeng YH, Song Y, Li J, Zhang WH, Shi B. Visualization and quantification of penetration/mass transfer of acrylic resin retanning agent in leather using fluorescent tracing technique. J Am Leather Chem As. 2016;111(11):398-405

22. Song $Y$, Wu SQ, Yang Q, Liu H, Zeng YH, Shi B. Factors affecting mass transfer of protease in pelt during enzymatic bating process. J Leather Sci Eng. 2019;1:4.

23. IUP 36. Measurement of leather softness.

24. Peng $\mathrm{WL}$, Zhang XL, Chen SR. The principle and method of testing leather fullness and softness. J Soc Leath Tech Ch. 2006:90(3):117-22.

25. Ding W, Yi YD, Wang YN, Zhou JF, Shi B. Preparation of a highly effective organic tanning agent with wide molecular weight distribution from biorenewable sodium alginate. Chemistry Select. 2018;3:12330-5.

26. Heidermann E. Fundamentals of leather manufacture. Darmstadt: Eduard Roether KG; 1993.

27. Tang YL, Zhou JF, Zeng YH, Zhang WH, Shi B. Effect of leather chemicals on $\mathrm{Cr}$ (III) removal from post tanning wastewater. J Am Leather Chem As. 2018; 113(3):74-80.

28. Tang $\mathrm{YL}$, Zhou JF, Zhang $\mathrm{WH}$, Shi B. Existence of $\mathrm{Cr}$ in post-tanning wastewater and influencing factors on its removal. China Leather. 2017; 46(11):7-12

\section{Publisher's Note}

Springer Nature remains neutral with regard to jurisdictional claims in published maps and institutional affiliations.

\section{Submit your manuscript to a SpringerOpen ${ }^{\circ}$ journal and benefit from:}

- Convenient online submission

- Rigorous peer review

- Open access: articles freely available online

- High visibility within the field

- Retaining the copyright to your article

Submit your next manuscript at $>$ springeropen.com 